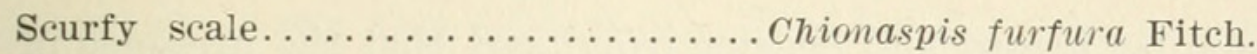

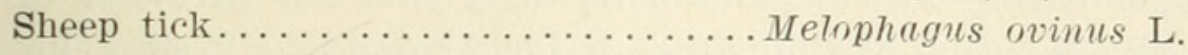

Silkworm ................... Bombyx mori L.

Spring canker-worm.............Paleacrita vernata Peck.

Squash borer............................

Squash-bug .................... Anasa tristis DeG.

Stable fly.........................

Stalk borer.................. Papaipema nitela Guen.

Strawberry crown-borer.............. Tyloderma fragariae Riley.

Strawberry leaf-roller............... Ancylis comptana Fröhl.

Strawberry weevil................. Anthonomus signatus Say.

Striped blister-beetle.............. Epicauta vittata Fab.

Tarnished plant-bug................ Lygus pratensis L.

Tomato-worm ......................

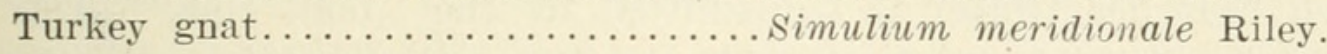

Variegated cutworm....................

Vagabond crambus....................

Walking-stick ................. Diapheromera femorata Say.

Walnut case-bearer...............Mineola juglandis LeB.

Walnut-sphinx ................... Cressonia juglandis S. \& A.

Wheat-head army-worm.............Heliophila albilinea Hbn.

Wheat midge....................

White-lined sphinx............... Deilephila lineata Fab.

Yellow mealworm................. Tenebrio molitor L.

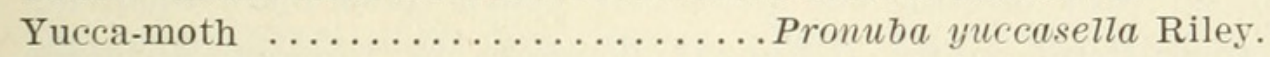

Zebra-caterpillar ....................

\title{
TICK-BORNE DISEASES AND THEIR ORIGIN
}

By Nathan Banks, Washington, D. C.

Texas or splenetic fever was first described as a disease of cattle in this country by Dr. J. Pease about 1795 from an outbreak at Lancaster. He concluded that it was due to an importation of cattle from North Carolina. Gradually it was discovered that when southern cattle were brought north in summer, northern cattle along the route would sicken and die, while northern cattle taken south also contracted the disease, although the southern cattle generally remained in good health.

It had long been known to eattle-raisers in the southern states that cattle dying from Texas or Spanish fever were infested with ticks, and it was therefore quite natural for them to attribute the disease to the tick. Veterinarians, however, did not believe it, and Gamgee, in his extensive report on the diseases of cattle (1869), argued against the supposed connection. In 1890 Dr. P. Paquin considered the tick as one agent in transmission, but he had little actual evidence. In 1889 Dr. F. L. Kilborne of the Bureau of Animal Industry, thought 
to test the popular theory and became convinced that the presence of the cattle-tick was necessary to the transmission of disease. Later, he, with Dr. T. Smith, proved that the tick was an intermediary host of the blood parasite causing the disease and in the same year Dr. Theobald Smith described the parasite as Pyrosoma bigeminum, now Piroplasma. The southern cattle accustomed to tick infestation from birth, become immune to the disease, but if not raised in tick-infested fields they are as susceptible to the disease as northern cattle.

Since 1890 many experiments by various observers have served to confirm Dr. Kilborne's results. Diseases similar to Texas fever occur in cattle in various parts of the world. In South Africa Lounsbury has shown that heartwater is transmitted by the "bont tick," Amblyomma hebrcum. Later he has shown that malignant jaundice in dogs is due to the attack of a dog tick, Haemaphysalis leachi, and that African coast fever in cattle is carried by five species of Rhipicephalus. In each case there are differences in the manner of infection and the stage of the tick capable of infecting an animal, and various peculiarities in the life history of each tick.

These discoveries have served to open a wide field of suspicion and investigation, so that during the past few years ticks have been accused of transmitting many different diseases to various animals. The evidence, however, in many cases, is far from conclusive, but, doubtless, as experiments are carried on proof will become established of the culpability of other ticks in the diffusion of disease.

Louping ill in sheep is thought to be carried by an Ixodes; spirillosis in fowls is attributed to an Argas; spotted fever due to the presence of a Dermacentor. A disease of turtles is laid up to Hyalomma agyptium; carceag, an European disease of sheep, is supposedly transmitted by Rhipicephalus bursa. An undetermined Ceylonese tick is credited with producing paranghi or "yaws." Infected specimens of Ixodes ricinus have given a piroplasmosis to European cattle; and the "moubata bug", (Ornithodoros moubata) is the inoculating agent of one of the most dangerous diseases dreaded by inhabitants of West Africa.

From the known results, it is evident that the power to transmit disease is not confined to any one genus or section of Ixodida, but common to all. Moreover, in different countries extremely similar diseases are carried by very different ticks. Therefore the diseases have not originated in the ticks. Most, if not all, of the species now acting as agents in the dissemination of disease to certain hosts were probably originally confined to other hosts. To their original or natural host they brought no disease. Certain low organisms living in 
the blood of the host were transmitted by the ticks to other animals of the same nature without serious danger. But when a tick containing the blood parasites of one, its natural, host becomes attached to a new and different kind of host, then the blood-parasite in this alien blood may originate a disease. The occasional transference of a tick from one host to another may not be sufficient, but when a species of tick practically changes its host, then a disease may result, provided, of course, that the ticks are commonly infected with a blood parasite of their old host.

This theory of the origin of these diseases, though new to me, I find has been proposed by Dr. H. M. Woodeock in a paper on the Hæmoflagellates." Doctor Woodcock was mostly concerned in the diseases transmitted by flies, but as he includes in his general review a reference to piroplasmosis, it is evident that he considers the tickborne diseases as originating in the same way as the others. Doctor Woodeock's statement follows: "It follows, however, from what has been said above, that the animals for which these parasites are markedly pathogenic cannot be regarded as their true or natural hosts, which are rather to be sought among the native, tolerant animals of the locality concerned."

In accordance with this theory then, the ticks in adapting themselves to the march of civilization, the extermination of native animals and the introduction of domestic animals, have here and there transmitted to domestic animals blood-parasites that are normally found in certain wild species.

The tick is a most necessary part in the life-history of these parasites, for in some cases (perhaps all) the sexual conjugation of the parasite is consummated within the body of the tick.

It is therefore evident that all ticks are potentially dangerous. Any tick now commonly infesting some wild animal, may, as its natural host becomes more uncommon, attach itself to some domestic animal. Since most of the hosts of ticks have some blood-parasites, the ticks by changing the host may transplant the blood-parasite into the new host, producing, under suitable conditions, some disease. Numerous invèstigators throughout the world are studying this phase of tick-life, and many discoveries will doubtless signalize the coming years.

* Quart. Journ. Micr. Sci. (N. S.) vol. 50, p. 158, 1906. 


\section{$2 \mathrm{BHL}$ Biodiversity Heritage Library}

Banks, Nathan. 1908. "Tick-borne diseases and their origin." Journal of economic entomology 1(3), 213-215. https://doi.org/10.1093/jee/1.3.213.

View This Item Online: https://www.biodiversitylibrary.org/item/37189

DOI: https://doi.org/10.1093/jee/1.3.213

Permalink: https://www.biodiversitylibrary.org/partpdf/325865

\section{Holding Institution}

New York Botanical Garden, LuEsther T. Mertz Library

\section{Sponsored by}

The LuEsther T Mertz Library, the New York Botanical Garden

\section{Copyright \& Reuse}

Copyright Status: NOT_IN_COPYRIGHT

This document was created from content at the Biodiversity Heritage Library, the world's largest open access digital library for biodiversity literature and archives. Visit BHL at https://www.biodiversitylibrary.org. 